\title{
EXTENDING THE GRASP OF THE DEAD HAND: REFLEGTIONS ON THE ORIGINS OF THE RULE AGAINST PERPETUITIES
}

\section{George L. Haskins †}

Henry Frederick Howard, the Earl of Arundel and Surrey, was a member of one of the oldest and most prominent families in England. In 1647 he was faced with the serious problem of how to provide for certain of his younger children through the disposition of one of his estates, the barony of Grostock. Thomas, the Earl's eldest son, was insane; yet by law upon his father's death he was entitled to succeed to the Earldom, which required enormous supporting family wealth. The insanity of Thomas posed no small problem to the Earl. Some provision had to be made for the possibility that Thomas might have a son who, if born, would in turn succeed to the Earldom and therefore should have its attendant estates. Moreover, there were also other children to be provided for. The Earl's desire was that his next eldest son, Henry, should have at least the income accruing from the barony of Grostock during Thomas' life; and if Thomas should die in Henry's lifetime without leaving male issue then living and if Henry acceded to the Earldom and its estates it was the Earl's intent that his third son, Charles, should have the income from the barony of Grostock. ${ }^{1}$

In light of the complicated situation that prevailed in the Howard family, it is not surprising that the Earl turned to Sir Orlando Bridgman, a man much like himself, to draft a trust instru-

i Algernon Sydney Biddle Professor of Law at the University of Pennsylvania. A.B., Ll.B., Harvard University. Member of the Philadelphia Bar; also of the Maine, Massachusetts and Pennsylvania Bars. Fellow of the Royal Historical Society (London) and member of numerous legal and historical associations in the United States and abroad.

This Article is a revised and greatly expanded version of the First General Address delivered by the author in Boston on November 5, 1977, before the American Society for Legal History.

The author is grateful to Alfred W. Putnam, Jr., a student at the University of Pennsylvania Law School, for invaluable assistance in the preparation of memoranda upon which portions of this Article are based.

1 See generally Barry, The Duke of Norfolk's Case, 23 VA. L. REv. 538 (1937). The Earl of Arundel was beset with an additional problem, apart from the insanity of his eldest son. His estates had been confiscated by Parliament, sometime prior to 1647 , undoubtedly in retaliation for his support of Charles $I$, who was fighting a pitched battle with Parliament over the religious and political issues that divided England in the 1640's. See id. 545-46. 
ment to accommodate the possibilities of descent. Bridgman, like the Earl of Arundel, was a Royalist in a suddenly republican England; he was also a brilliant lawyer who chose not to appear before the courts during the Commonwealth period of 1649-1660, but became instead a renowned conveyancer. ${ }^{2}$ The trust indenture that Bridgman drafted became the basis for the celebrated legal battle between Henry and his younger brother, Charles, now known as The Duke of Norfolk's Case. ${ }^{3}$ Although the narrow issue decided by Lord Nottingham was which of the two brothers was entitled to the barony of Grostock, The Duke of Norfolk's Case became famous, or perhaps infamous, as the case in which the elements of the Rule Against Perpetuities were first announced.

The Rule Against Perpetuities is among the oldest, most respected, and difficult to understand rules of the common law. The purpose of this Article is not to illustrate the complexity of the rule or its potential applicability to countless fact situations, but rather to attempt to explain why the rule was thought necessary, and how it came to be the method for determining what is, or is not, a void perpetuity.

Although few lawyers today would be willing to describe themselves as certain of their ability to apply the rule to all possible cases, most have little doubt about the rule's underlying policy reasons. It is, after all, a rule against perpetuities and thus is generally considered to be one of the law's weapons against restraints on the alienation of property. Indeed this has always been the accepted explanation: "Ever since it first emerged in The Duke of Norfolk's Case, it has been declared to be a rule in furtherance of the alienability of property." 4 According to this view, a rule favoring alienability was necessary by the end of the seventeenth century because " 'perpetuities' impeded the development of the mercantile middle class by taking property out of the 'stream of commerce." " 5 In a society that has been portrayed as changing from a feudal to a capitalist order, the creation of a new rule restricting a landowner's ability to tie up his lands would, not surprisingly, be perceived as proof of such a transition. Land, the

2 See id. 546.

33 Ch. Cas. 1, 22 Eng. Rep. 931 (1682).

4 Simes, The Policy Against Perpetuities, 103 U. PA. L. Rev. 707, 708 (1955). Simes questioned the continued validity of such a rationale, concluding that two other justifications are superior: (1) the rule strikes a fair balance between property rights of the present generation and those of future generations; (2) the rule advances the socially desirable policy that the wealth of the world should be controlled by its living members and not by the dead. Id. 723 .

5 Grimes, Runnymeade Revisited, 6 VAL. U. L. REv. 135, 136 (1972). 
source of all wealth in a pre-capitalist society, had to be made more marketable. Once the major restraints on alienation were removed, successful men would rise and the incompetent would fall, regardless of the efforts or the prominence of their ancestors. This perception of the rule as promoting a laissez-faire system is articulated in the Restatement of Property: "It is obvious that limitations unalterably effective over a long period of time would hamper the normal operation of the competitive struggle. Persons less fit, less keen in the social struggle, might be thereby enabled to retain property disproportionate to their skills in the competitive struggle." 6

The traditional explanation of the origins of the rule is contradicted, however, by several compelling factors and is therefore ripe for reexamination. Obviously the modern common law rule, which states that an interest in property is void unless it will necessarily vest, if at all, within a life in being and twenty-one years, ${ }^{7}$ limits a testator's or grantor's ability to control the future ownership of his land, or other property; but the limit is a generous one, as generous as most rational property owners would want. The rule that was first announced by Lord Nottingham in The Duke of Norfolk's Case had a different purpose. In fact, it was then called a rule of perpetuities not a rule against perpetuities. The Duke of Norfolk's Case was a clarification of ancient contradictory assumptions, decisions and uncertainties with respect to how long interests in landed property might last. Moreover, the decision was not simply the resolution of an arcane point of property law: the case marked the climax of a long struggle between the conveyancers who wanted more freedom for the landed classes to control their estates and the royal judges who stood firm against these efforts for centuries. The conveyancers and their clients, not the judges, were the ultimate victors.

This conclusion, which is so contrary to traditional assumptions about the origins and purposes of the rule, is suggested by three related inquiries. First, there is the question of interpreting the economic, social, and political forces at work in seventeenth century England. A generation ago it was fashionable to view this period

64 Restatemant of Property, Introductory Note at 2132 (1944). It was Professor Leach's view that the rule was intended to remove the "threat to the public welfare from family dynasties built either on great landed estates or on great capital wealth." Leach, Perpetuities in Perspective: Ending the Rule's Reign of Terror, 65 HANv. L. REv. 721, 727 (1952).

7 The definitive modern version of the rule was formulated by John Chipman Gray, the high priest of the Rule Against Perpetuities: "No interest is good unless it must vest, if at all, not later than twenty-one years after some life in being at the creation of the interest." J. Grax, The Rule Agarnst Perperuiries (4th ed. 1942) $\$ 201$. 
as dominated by a rising middle class wedded to capitalist ideas such as free alienability of property. Now, however, a new climate of opinion has emerged, and an increasing number of historians have accepted the theory that the dominant ethos of the seventeenth century was that prevailing in a landed class generally hostile to mercantile or capitalist ideas. Such a class might be expected to take a jaundiced view of the free alienability favored by eager city buyers. Second, an examination of the law existing before the new rule was adopted reveals that the new rule did not limit a testator's or grantor's options but rather afforded him greater flexibility by enhancing, his ability to control future ownership of his property. Third, the facts of The Duke of Norfolk's Case reveal the problems that faced a great landowner before he had the rule to rely on and how that rule alleviated those problems. An examination of these three lines of inquiry leads to a rejection of the traditional theory set forth by the Restatement and other classic authorities.

\section{Seventeenth Century England}

The traditional theory about the origins of the Rule Against Perpetuities was virtually unassailable a generation ago because it matched nicely with the accepted historical interpretation of seventeenth century England, which was largely influenced by Marxist views. ${ }^{8}$ The Marxist interpretation of the social struggle of the 1640's was championed by R. H. Tawney, a distinguished Socialist historian who was instrumental in developing a new social and economic historiography in Great Britain. ${ }^{9}$ According to Tawney the Revolution in 1642 represented the triumph of the emerging middle class' newer capitalist values over the older feudal structure. Tawney saw the gentry as a rural middle class rising against the increasingly decrepit feudal ruling class of the aristocracy, and thus the gentry, although a landed class, was given an unwarranted capitalist hue. ${ }^{10}$ The gentry's religion was Protestant, their political

8 The Marxist analysis was itself a reaction to the Whig interpretation of seventeenth century English history, which had emphasized the advancement of political and religious liberty. Typical examples of Whig historiography include G. Trevelyan, The Two Party System in English Polmtical History (1926); G. Trevelyan, British Histonx iN teer Nineteenth Century (1782-1901) (1922); T. Macaulay, The History of England From the accesston of James the SECOND (1879).

O Tawney's economic analysis of the seventeenth century was put forward in R. Tawney, The Rise of the Gentry, 1558-1640, II Econ. Hist. REv. I (1941). Other works by Tawney include R. Tawney, Retrgion and tre Rrse of Caprraursm (1st ed. 1926); R. Tawney, Harrington's Interppetation of His Age (1942); R. Tawnex, The Agrarian Problem in the 16tr Century (1912).

10 See Tawney, The Rise of the Gentry, 1558-1640, supra note 9, at 12-18. 
instincts were parliamentary and their economic views ivere mercantile or capitalist. These words are, of course, only labels, but they serve to depict the Marxist perception of a class that might be expected to include in its list of reforms a rule that would tie the hands of great landed lords, who sought to protect their estates from the economic misfortunes that were overtaking them as a class. When the triumph of this bourgeois gentry came, capitalist values triumphed as well. Given the favour that this historical interpretation enjoyed twenty-five years ago, ${ }^{11}$ the rule, born in the early 1680's, explained itself. The traditional theory of the rule's origins matched and, therefore, it had to be correct.

Unfortunately, the traditional theory no longer fits. The Marxist interpretation was flawed from the outset and was soon under attack. The first assault came in 1953, when Professor H. R. Trevor-Roper argued with great force that the gentry was in fact a declining class of small landowners driven to revolution by economic reverses and the sullen resentment of an increasingly dominant court. ${ }^{12}$ Trevor-Roper's view was ultimately too extravagant to be maintained, but it did illustrate the weakness of Tawney's approach. A more persuasive argument was put forward by J. H. Hexter in 1961.13 Hexter was convincing on two points that were devastating to the effort to describe the seventeenth century as a period of capitalist triumph. First, he suggested that there was nothing unusual about the movement of members of the middle or trading classes into the landed class: "From the fourteenth century comes that classical example of the rise of the middle class, the de la Poles who went from trade at Hull to the Earldom of Suffolk in two generations." 14 Pointing to the Pastons, Caxtons, and Chaucers, Hexter concluded: "And so back through the centuries, as far as the record will take us, we find the rising middle class making its way out to the land, buying estates from aristocrats too unlucky or thriftless to hold them." 15 The newly triumphant class of the seventeenth century was nothing new. When new men did replace old,

11 Tawney initially swept many before him, and many an article was devoted to the influence the gentry had on politics, economics and law. See, e.g., Stone, The Anatomy of the Elizabethan Aristocracy, 18 Econ. Hrst. REv. (1948); Thorne, Tidor Social Transformation and Legal Change, 26 N.Y.U.L. REv. 10 (1951).

12 Trevor-Roper, The Gentry 1540-1640, Econ. Hrst. Rev. (1953) (Supp. I).

$13 \mathrm{~J}$. Hexter, The Myth of the Middle Class in Tudor England, reprinted in Reappratsats IN History 71 (1962); J. Hexter, Storm Over the Gentry, reprinted in ReAppratsats IN Histony 117 (1962). at 79 .

$14 \mathrm{~J}$. Hexter, The Myth of the Middle Class in Tudor England, supra note 13,

$15 I d$. 
they were generally replacing the grandsons of men who had themselves been new.

Second, and more important, Hexter rejected the idea that the gentry, however long they had been on the land, could be considered as anything other than a landed class. The seventeenth century merchants who bought land were diverting capital into an investment that promised no better than a five percent return. Had they left their money in the city, they could have been assured of a ten percent return. ${ }^{16}$ These individuals were willing to accept a lesser income because they coveted the prestige that went with land. The new men were more interested in behaving like landed gentlemen than in earning the kind of profit that would lure a true capitalist. The landed gentleman remained the ideal to which all propertied classes aspired. The newly landed class was, on the whole, no more nouveau riche than the aristocrats that Tawney would have us believe were their rivals.

Conrad Russell, another distinguished historian, has described the difficulties faced by those who differentiated the landed gentry from the landed aristocracy:

In economic terms, both had the same relationship to the means of production: they lived off the profits of landownership ... [ [B]y any test which can be devised they must be regarded as being of the same class. There is no justification for describing gentlemen as "middle class." The term "middle class," and even more the term "bourgeois," are urban ones, and are very hard to fit into the class structure of rural England, in which people were either gentlemen or not gentlemen.17

If the rising class was neither particularly new, nor particularly capitalist, the basis for the traditional view of the rule's origins becomes even more doubtful. To this doubt must now be added two additional factors.

First, the work of the economic historians has not gone for naught. By the early years of the seventeenth century the landed classes, regardless of the values to which they aspired, were clearly undergoing considerable and continuing economic upheaval. Whether rising or falling as individuals, the members of the landed class as a whole were increasing in numbers. Lawrence Stone has estimated a threefold increase between 1540 and 1640: "The number

16 Id. 96.

17 C. Russeli, The Crists of Parltaments 17-18 (1971). 
of peers rose from 60 to 160 ; baronets and knights from 500 to 1,400; esquires from perhaps 800 to 3,000 ; and armigerous gentry from perhaps 5,000 to $15,000 . " 18$ The growth of the landed classes, coupled with the availability of land that resulted from the confiscation of the monasteries and the frequent sale of crown lands to finance foreign adventures, resulted in a highly speculative land market. The market peaked between 1615 and $1620,{ }^{19}$ but the activity is illustrative of the economic insecurity of the entire period. Stone concluded that "[a] landed aristocracy has rarely had it so bad." 20

The crux of both Stone's and Hexter's analyses is that the landed families were having great difficulty in holding on to their estates. The instability of the families themselves is reflected by the fact that of the 63 noble families existing in 1559, only one-third had lasted without total or partial failure of succession on the eve of the civil war in 1641.21 Those families that did not suffer from too few children often had too many and daughters were particularly unwelcome in light of the increasing expenses of marriage. ${ }^{22}$ Stone points to the failure of landed fathers to provide for their families as one of the reasons for the insecurity associated with the troubled land market; in addition, "legal obstacles to breaking entails and selling land were exceptionally weak, and moral objections to the dismemberment of the family patrimony exceptionally feeble." 23 (1972).

18 L. Stone, The Causes of the English Revolution 1529-1642, at 72 $19 \mathrm{Id} .73$.

20 L. Stone, The Crusis of teme Arustocracy, 1558-1641, at 94 (abr. ed. 1967). 21 Id. 79.

22 Id. 81.

23 Id. 94. Hexter, relying on an earlier work of Stone's, described the moral decline of one seventeenth century family:

Consider the sad case of Toby Palavicino. He inherited one of the most magnificent landed fortunes in Cambridgeshire. His rake's progress from the time he came into his own to the time he lay "in the Fleet for debts" took sixteen years; but then Toby was handicapped. His prudent father had laid an entail on the estate, and Toby was put to all the bother of getting an Act of Parliament passed to break it. Had it not been for this tiresome hindrance, he might have made it to jail several years sooner.

J. Hexten, The Myth of the Middle Class in Tudor England, supra note 13, at 93. The Palavacino case is an interesting one because the prudent father who sought to use the entail to tie up his property was not an heir of an established family, but a self-made Elizabethan financier and alum trade monopolist who had finally ascended into the landed class. His urban, mercantile background did not carry with if any loathing of entails; quite the contrary, rather than seeking a device to enhance the alienability of his land, Palavicino Sr., like any great landowner, sought to save his vast wealth from the irresponsibility of a reckless son. It is not clear why an act of Parliament was required to break the entail, which normally could be barred by a 
The second consideration that must be evaluated is the date of the rule itself. Although the great debate over the gentry has concentrated on the economic instability of the pre-civil war period, the Rule Against Perpetuities was propounded well after the Cromwellian revolution, in 1681. The political mood of this later period was distinctly conservative. After the restoration of Charles II to the throne in 1660, the landed classes entered a period of relative stability and confidence. There was still considerable political turmoil, ${ }^{24}$ but the dominant sentiment was Tory. The Tory philosophy was pro-monarchy, but the King's cause was not its sole or even pre-eminent guiding star. The Tory's first loyalty was to the Church of England, and the political crises of the Restoration Parliament were generally the result of Royal efforts to tamper with the established religion. ${ }^{25}$ In addition, the Tory was generally a landed gentleman, with little love for merchants, the city of London or capitalism. Even the Marxist historians have never attempted to depict these men as capitalists. The liberal ideas the Marxist-oriented historians sought to ascribe to a rising middle class were in fact tied to the makers of the Revolution of 1642, who were predominantly members of dissenting religious sects and held more liberal political views. ${ }^{26}$ The Tories of the post-revolutionary period were the reaction to the Cromwellian revolution, and one of these men, a prosperous Kent landowner, the Earl of Nottingham, first enunciated the Rule Against Perpetuities.

recovery, unless the property was in trust and the trustees could not join without a breach of trust. See generally L. Stone, An Eluzabetran: SiR Horatio Patavicino (1956).

24 The reigns of Charles II and James II, lasting jointly from 1660 until 1689, were in fact noted for considerable political debate, and for the development of a two party system. The Whig Party, generally tied to the older parliamentary tradition of Cromwell's Roundheads, was an amalgam of dissenting religious groups, political liberals, merchant interests and out of favor courtiers. See generally J. Jones, Ther Frrst Wrigs (1961). The Tory Party, dominant in the seventeenth century, was Royalist, strongly Anglican, and landed. See generally K. Femivg, A History of the TORY PARTy 1640-1714 (1924). For a good general work on the political, and non-political, conflicts of the period, see D. OGG, ENGLAND IN THE reign of Celartes II ( $2 \mathrm{~d}$ ed. 1956).

25 Modern historians have persuasively demonstrated that Tory opinion was separable from Royalist opinion, and that it was the Tory majority in the House of Commons that rejected royal attempts at religious toleration, first in 1660-61, and then more decisively in 1673. Tory hostility to Catholicism led to the temporary decline of the party in the wake of the Popish plot hysteria and to a momentary majority for the Whigs in 1679-81. In light of the Tory hostility to toleration of either Catholicism or dissenting Protestantism, the effort of James II to tolerate both groups resulted, not surprisingly, in the overthrow of the Stuarts. For the best discussion of the Tory point of view, see D. Witcombe, Charies II AND THE Cavalier House of Commons 1663-1674 (1966).

26 G. Davies, The Eardy Stuarts, 1603-1660, 127-30 (2d ed. 1959). 
The Rule Against Perpetuities therefore seems to be the work not of incipient capitalists but of landed gentlemen anxious to preserve the positions of their families in a society that had recently passed through a turbulent period. If this explanation of the rule's origins is true, the question remains why the landed gentry should want a rule against perpetuities. Would they not prefer a rule that might give a landed gentleman a little more freedom to tie up land? Clearly they would, and that is precisely what Lord Nottingham gave them.

\section{The LAW Before The Duke of Norfolk's Case}

In the beginning was the land. Its importance in the history of England and English law continued to grow from the Middle Ages until at least the end of the eighteenth century. Land was the basis of economic subsistence, wealth, family solidarity, social status and above all security. Feudal doctrine prescribed that land should be held of an overlord, and ultimately of the king, so that rules with respect to its transfer and descent tended to reflect policies of the crown embodied in the common law of the king's courts. It fell to the royal courts to formulate rules that sought to balance the conflicting interests and desires of the king and of his powerful landed subjects, who had a strong and ingrained sense of what they should be permitted to do with, and how they might dispose of, their land and property rights. The rules that restrained the landowners, however, were rigid and sometimes complex. Occasionally they required modification, as by the Statute De Donis, which in 1285 created the fee tail. ${ }^{27}$

Although the royal judges often declared that land should be freely alienable, that alienability was limited by a recognized calculus of estates that had evolved well before the end of the reign of Edward $I$ in 1307. Thus, by the end of the thirteenth century, a man could typically convey land in the form of a life estate, a fee tail or a fee simple. Also, while retaining the underlying seisin and future right to repossession, a grantor might convey the possession of land for a term of years gratis, or for a stated rent. Within this calculus, however, there were restrictions on the conditions a man could impose on the grantee of his land. Some of these restrictions resulted from incapacities of thought connected with the elusive concept of seisin, ${ }^{28}$ while others resulted from royal policies hostile 
to the accumulation of large estates which, as the basis for private armies, might threaten the power of the king. ${ }^{29}$ Paradoxically, the first major challenge to the free alienability of land came when the Statute De Donis created a new estate that was in the beginning not truly alienable, the fee tail referred to above. The fee tail became unbarrable and could be conveyed by one in possession for his life only; then it would pass in any event successively to the family of the original grantee, generation after generation, until the lines ran out. The statutory unbarrable fee tail replaced the fee simple conditional, ${ }^{30}$ and it lasted for centuries, despite grave dissatisfactions and attempts to circumvent it. Increasingly during those years the problem became the practical one of marketability: a grantee might take land in good faith believing it to be freely alienable as the equivalent of a fee simple only to discover subsequently that the land had been entailed several generations back, that the lineal descendents of a prior grantee had died out, and that now a valid claim might be asserted by the heirs of the reversioner or remainderman under the original grant. Apparently, so much of the land in England had been tied up in entails of this sort that it became unsafe to take a conveyance lest one lose it in the manner described. ${ }^{31}$ The judges solved this problem in Taltarum's Case ${ }^{32}$ through the judicially recognized fiction that permitted a tenant in tail to break the entail, together with ensuing remainders and reversions, by "suffering a recovery." 33 Through the device of the common recovery the fee tail became freely alienable by the person in possession and that

29 The protection of the king's interests played a major role in the development of a rule against perpetuities. The greatest danger faced by many medieval kings was the overmighty subject and the preservation in perpetuity of a single family's financial base in land and men that might raise up a power capable of challenging the Crown itself.

The king's own financial interests were at stake as well. A perpetuity kept land out of the market and discouraged trade, thus limiting the king's revenues and taxes on the one hand and diminishing productivity on the other. Powelx, REstatement of Property, Prejimonary Draft 5 n.83; Poweld, 5 The law of Real Property I759[1] at 538 (1971). More importantly, a real perpetuity would deprive the king of the feudal incidents that were so vital to the royal treasury. This was Bacon's argument against perpetuities in Chudleigh's Case, 1 Co. 120a, 76 Eng. Rep. $270(1595)$.

30 The courts had declared the fee simple conditional to be freely alienable after the birth of issue. I Restatement of Property $\$ 70$ (1936). The process by which the fee tail became "unbarrable" is described in 3 W. Hocosworte, A History of Enguish Law 115-18 (1935).

31 See I Restatement of Property (Appendix) (re dower rights).

3212 Edw. IV 19, pl 25 (1472). Ingenious lawyers had earlier discovered other methods of evading De Donis in certain situations. See 3 W. HoLDswortr, supra note 30 , at $118-20$.

33 For a concise explanation of the procedure of the common recovery, see A. Casner \& W. Leach, Cases and Text on Property 256-58 n.I3 (2d ed. 1969). 
person could effectively convey an estate in fee simple absolute. ${ }^{34}$ Under the Tudors, landowners and their increasingly imaginative conveyancers were persistent in their efforts to establish long-lasting settlements of land, often by attempting variations on the basic fee tail. One such effort was the attempt to resurrect the unbarrable fee tail by adding a condition to the effect that any attempt to break the fee tail would immediately terminate the estate of the person attempting the disentailment. These conveyances were held invalid in several decisions in the early seventeenth century as repugnant to the fee tail; they were even described as perpetuities because, if given effect, the fee tail might then last forever-a continuity whose existence belonged only to God. ${ }^{35}$ Another example of the effort to circumvent the vulnerability of the fee tail was the creation of an equivalent to the estate tail in a long term for years. Unfortunately for the landowners, the courts struck this devise down at an early date, declaring that a term for years could not be entailed and that the first taker became the owner of the entire term. ${ }^{36}$

At about the time that Taltarum's Case had dealt a death blow to the fee tail as a device for tying up land, a second major threat to ready marketability arose. Assisted by the new types of estates made possible by the Statute of Uses ${ }^{37}$ in 1535 , conveyancers had also begun to tie up land through contingent remainders. Conveyances of successive interests to living persons-characteristically, vested remainders or reversions following estates for life or in fee

34 Taltarum's Case is important because just as the mortmain acts of the time of Edward I sought to keep the Church from accumulating large areas of land, the development of the common recovery was similarly inspired by the growing concentration of great estates in the hands of powerful families. After Taltarum's Case, the fee tail could in theory last forever in the heirs of the owner to whom it was sold or given, but at any time the current owner might suffer a common recovery and thereby transfer the land back into the mainstream of commerce.

35 Corbet's Case, 1 Co. 83b, 21 Eng. Rep. 985 (1599), quoted in G. CArY, Reports or Causes in Chancery 11 (1820).

36 Sanders v. Cornish, Cro. Car. 230, 79 Eng. Rep. 801 (1631). By the end of the sixteenth century the conveyancers, spurred on by their worried landed employers, sought to create unbarrable entails through a clause of cesser. Gray notes an interesting contemporary reaction to this sort of perpetuity that has been attributed to Lord Bacon:

There is started up a device called perpetuity; which is an entail with an addition of a proviso conditional tied to his estates, not to put away the land from the next heir; and, if he do, to forfeit his own estate. Which perpetuities, if they should stand, would bring in all the former inconveniences of entails that were cut off. . . .

7 Bacon's Works 491 (Spedding's ed. 1859) quoted in J. Gray, supra note 7, $\$ 141.2$. The courts were not fooled, however, and Professor Yale has suggested that they disposed of this threat by Coke's time. D. YALE, INTRODUCTION To 1 Lorn Nottungham's Chancerry Cases lxxiv (1957). See Corbet's Case, I Co. 83b, 21 Eng. Rep. 985 (1599); Mary Portington's Case, 10 Co. 35a, 77 Eng. Rep. 976 (1614). 
tail-were countenanced in the middle ages. Six hundred years ago, these basic future interests, which take effect whenever and however the immediately preceding estate ends and with no other condition attached, were viewed as present interests, with enjoyment postponed.

It was otherwise with remainders granted on a contingency or to an unascertained person. Contingent remainders were indeed future interests, but the law gave them scant recognition until the sixteenth century, ${ }^{38}$ for it was not perceived how an owner could be seised of such a freehold interest if he were unknown, or if a condition were attached to his taking it. From this conception there developed two related rules, fortified by such other considerations as the strong preference for alienability; and it became law that a contingent remainder could be destroyed by persons having actual seisin, or the remainder would fail if the condition were not satisfied in time for it to vest in possession or in interest before the preceding estate, usually an estate for life, ended. These two rules are respectively known as the artificial and natural destructibility of contingent remainders.

A contingent remainder in realty, unless in trust and hence equitable, was subject to destruction if the condition attached to it had not been satisfied at the termination of the preceding or "supporting" freehold estate, typically a life estate. Even though the condition might be subsequently met, or the grantee be later identified, the common law refused to tolerate a gap in seisin; and a gap would appear if a condition, express or implied, attached to such an estate had not been met. This reasoning required what has been referred to above as natural destructability. ${ }^{39}$ Only those holding an estate for life, in fee tail, or in fee simple could be seised.

Notwithstanding the legal thrust and counter-thrust that surrounded the fee tail, the landowners were aware that the law was doing their work. If many a landed gentleman wished to guard against the mismanagement of a foolish heir, most of them also realized that a genuine perpetuity posed the danger of depriving a family of economic flexibility in selling land when changing economic circumstances required re-investment or ready cash. The worries created by the spectre of a genuine perpetuity, such as an unbarrable entail, are reflected in a bill brought in the House of Commons in 1597 which found that such perpetuities

[E]ngender discorde in all families where they light and drawe the whole kindred into faction, but doe also make Children disobedient and parents unnatural .... [M]any purchasers are often and usually defrauded by such [perpetuities] and the owmers of inheritance of landes restrayned from raysinge money by sales or from exchanginge Lands for lands upon any occasion whatsoever. ...

Holdsworth, An Elizabethan Bill Against Perpetuities, 35 L.Q. Rev. 258, 258 (1919). 3727 Hen. VIII, c. 10 (1535).

38 J. Gray, supra note 7, $\$ 134-35$ (4th ed. 1942).

39 See, e.g., White v. Summers, [1908] 2 Ch. 256. 
The rule had evolved from the practicalities of the feudal system, which demanded that someone should always be seised or "sitting upon" the land and be responsible for feudal dues; but the reasons for the rule had become encysted in the tissues of judicial thought, and, aided by conceptions favorable to freer alienability, the rule was relentlessly applied. Conveyancers who hoped that an equitable contingent remainder, transformed by the Statute of Uses into a corresponding legal estate, would be indestructible were dismayed to find the judges deciding that even those remainders were equally subject to destruction. ${ }^{40}$ The same pressures in favor of alienability, supported by convictions as to the fragility of non-vested remainders also permitted contingent remainders to be destroyed by a conveyance from a life tenant to the owner of the next vested estate, usually the reversioner, thereby squeezing out the intervening contingent remainder if the condition had not yet been met. This process, known as merger, is what has been referred to above as artificial destructibility. ${ }^{41}$

To be safe from the common law rules that continued to emphasize the anachronistic concepts of seisin, a seventeenth century landowner might convey land to trustees in such a way that the Statute of Uses would not transform the equitable interest into a corresponding legal estate, for example, by conveying the interest with active duties. Seisin would be in the trustees, and the gaps, fatal at law, were immaterial in equity insofar as an equitable contingent remainder was concerned. Apparently, however, landowners were reluctant to give up the legal ownership of property and transfer it to trustees, for they would then lack the power to break the trust and to sell in a rising market for profit or to meet current financial needs. Nevertheless, the trust device was there, and it continued to be a potential threat to free alienability of land insofar as the two rules of destructibility were concerned. As will appear, conveyancers in the seventeenth century turned to the use of terms for years, where their clients could retain the basic seisin and yet create future interests-whether absolutely or, more usually, in trust-within a term.

By the early seventeenth century the struggle for free alienability had met with considerable success. ${ }^{42}$ Destructibility of fees tail

40 Chudleigh's Case, I Co. 120a, 76 Eng. Rep. 270 (1595).

41 See, e.g., Purefoy v. Rogers, 2 Wms. Saund. 380, 85 Eng. Rep. 1181 (1670).

42 Other evidence of legal rules favoring free alienability can be found in the articulation of a rule recognized in D'Arundel's Case, 3 Bracton's NotE Book, case 1054 (F. Maitland ed. 1887) (1225), and canonized in Shelley's Case, 1 Co. 93b, 76 Eng. Rep. 206 (1581). The Rule in Shelley's Case prescribed that in 
by common recovery and of legal contingent remainders by merger and failure to vest had become so effective a weapon that it was fast becoming a rule against perpetuities itself, particularly because certain of the new types of legal executory interests made possible by the Statute of Uses were considered destructible as contingent remainders. ${ }^{43}$ Quite unexpectedly in 1620, the Court of King's Bench re-emphasized in Pells $v$. Brown ${ }^{44}$ that there was a generic and not merely verbal distinction between executory interests and contingent remainders. The judges held that an executory interest could not be destroyed, despite a strongly worded dissent that the majority's holding would lead to a "mischievous kind of perpetuity." 45 It should be emphasized that for these purposes the word perpetuity connoted an inconvenient fettering of property in the sense that the interest created in a grantee might be inalienable for too long a time. ${ }^{46}$

The facts of Pells $v$. Brown were relatively simple. ${ }^{47}$ William Brown Sr. left his farm to his second son Thomas, but if Thomas should die without issue in the lifetime of William Sr.'s first son, William Jr., the farm was to go to the latter. Thomas apparently believed he owned a fee tail and he did what the law encouraged people to do when their land was tied up in fee tail: he suffered a common recovery to convert the fee tail into a fee simple and subsequently devised the land to the Pells family. His death without issue in William Jr.'s life raised the question whether the future interest of his brother William was good, or whether preference for free alienability would be given free reign with the termination

certain situations a conveyance to a grantee for life and then to his heirs gave the grantee not a life estate and a remainder in unascertained heirs but a remainder in himself and hence, by merger, a fee simple. A comparable rule emerged from the doctrine of worthier title. See 3 Restatement of Property $\$ 314(1)$ (1940).

43 See J. Gray, supra note 7, $\$ 159$. Devices for tying up land had not been disposed of altogether, however. The use of trusts was possible, although this could require transfer of the seisin as well. After the Statute of Uses it was possible as well to create contingent remainders after a term of years, but they were recognized only as springing executory interests.

44 Cro. Jac. 592, 79 Eng. Rep. 504 (1620).

45 Id., 79 Eng. Rep. at 506.

464 Restatement of Property, Part 1, Introductory Note (1944). See T. Scrutton, ILAND IN FetTers 123-33 (1886).

47 The report for Pells $v$. Brown indicates that the case was an action in replevin for the taking of three cows at Rowdham. Apparently Pells' cows were taken by William Brown under a claim that the cows were grazing on his freehold. Pells responded that the freehold in fact belonged to him rather than to William Brown, since William's brother Thomas had previously sold Pells the land. William's answer was a claim that he had a valid executory interest in the land and that Thomas was not free to convey the property. The replevin issue thus had to be resolved by deciding whether Pells or Brown owned the freehold. 
of William Jr.'s interest by the common recovery. The Court of King's Bench held first that Thomas did not have a fee tail but a fee simple subject to an executory interest because the failure of Thomas' issue was to be determined at a specific point in time, namely in William Jr.'s life. ${ }^{48}$ This was not so surprising. What astounded the lawyers of the time was that the court subsequently held that William Jr.'s interest was an indestructible executory interest.

The result in Pells v. Brown was truly revolutionary. J. S. Grimes, believing the case to be a victory for the landed interests, described it as "the new Runnymeade." 49 Whatever one thinks of Grimes' interpretation of Magna Carta, there can be no doubt that Pells $v$. Brown gave the conveyancers much more flexibility to control the future ownership of land than they possessed since the fee tail was held to be destructible in Taltarum's Case. Doderidge, one of the judges on the King's Bench dissented strongly: "[T]he recovery should bar William; for he had but a possibility to have a fee. . . which is destroyed by this recovery before it came in esse: for otherwise it would be a mischievous kind of perpetuity which could not by any means be destroyed." 50

Doderidge may have overstated his case, perhaps because he thought any abandonment of the principle of destructibility of future interests, whether by common recovery or by merger and failure to vest, was a surrender to the concept of a perpetuity. Farmer Brown had not, however, tied up his land perpetually. What he had done was to limit Thomas' ability to dispose of the land until either William Jr. died or Thomas himself died leaving issue. Thomas or his issue when in possession could have easily destroyed the fee tail if it had been one. William Jr.'s interest in turn would necessarily come into being within his own lifetime because he had to survive his brother. William Jr.'s interest was not the sort of future interest that would continue forever as a perpetual clog on the estate. Only Thomas' hands were tied.

Paralleling the development that culminated in Pells v. Brown was another that climaxed in Manning's Case ${ }^{51}$ in 1609. Before Manning's Case was decided the owner of a term of years who at-

$48 \mathrm{On}$ the other hand, if the devise had indicated no specific time at which the existence vel non of issue had to be determined, the failure of issue would have been indefinite and then Thomas would have owned a fee tail, which would terminate when his line actually died out.

49 Grimes, supra note 5, at 140.

50 Cro. Jac. at 506, 79 Eng. Rep. at 506.

518 Co. $94 \mathrm{~b}$ (1609). 
tempted to divide the term into a life estate in one person and what appeared to be a remainder in another, would find that the remainder was void. The conception of freehold estates and the dignity that lay behind that conception was, roughly speaking, that a life estate engulfed a term for years; therefore, the effect of the pre-1609 view was that the life tenant owned the entire term, and after his death, he might provide for the disposition of whatever remained of the term. A grantor was thus not permitted to fetter alienability even within a term for years.

In Manning's Case the judges of the Court of Common Pleas considered whether Edward Manning could leave an interest in a fifty-year term to his wife, Mary, and then to Matthew Manning. They decided that the life tenant did have a complete interest in the term under the traditional analysis, but it was subject to the condition that upon Mary's death Matthew's interest was not a void remainder but a valid executory interest. Even though Manning's Case involved a leasehold interest in a term for years, that is a chattel real, rather than real property, conveyancers seized on the decision as a method of tying up their clients' land, so that a freehold owner might theoretically create a 500 -year term in one person with succeeding indestructible executory interests in others in such a manner as to fetter the land until the full expiration of 500 years. In fact, so long a term was very unusual: the commonplace grant seems to have been a term that would last for the lives of several named individuals, and shift successively as executory interests on conditions operative at the deaths of one or more of those persons. ${ }^{52}$

Gray has pointed out ${ }^{53}$ in his review of decisions concerning perpetuities in the eighty years preceding The Duke of Norfolk's Case that with two exceptions ${ }^{54}$ all the decisions relating to the growth of the Rule Against Perpetuities involved terms for years and not freehold estates. Hence, the conveyancers' chosen arena was one in which they had greater apparent ability to tie up land. This was their "out" after Pells v. Brown.

Several reasons may be advanced for the increasing use of terms for years, rather than freehold estates by conveyancers as a technique of estate planning. First, considerable doubt persisted as to the soundness of Pells $v$. Brown, not only among conveyancers but among the judges. The case was a sudden and unexpected de-

52 See generally Gray, supra note 7 , at $\$ \$ 161-68$.

53 Id. $\$ 160$.

54 Snow v. Cutler, 1 Lev, 135, 1 Keb. 752, 83 Eng. Rep. 335 (1664); Taylor v. Biddal, 2 Mod. 289, 86 Eng. Rep. 1078 (1678); see J. GrAY, supra note 7, at $\$$ 165, 172. 
parture from pre-existing law, which as stated had considered executory interests to be as freely destructible as contingent remainders. ${ }^{55}$ To hold that an executory interest could not be barred by a recovery "went down with the judges like chopped hay." 56 Chief Justice Treby remarked: "These executory interests had not long been countenanced when the judges repented them; and if it were to be done again, it would never prevail." 57 After Manning's Case, which recognized executory interests within a term for years, those interests would not be destructible ${ }^{58}$ or even void and clearly not destructible by analogy to freehold estates since in the case of a term the seisin lay with the remainderman or the reversioner. A second possible reason for the growing use of terms and future interests within them may relate to the fact that the reversioner who created the term usually retained the fee in himself and also the title deeds, which would enable him to sell or mortgage the basic title, subject to the outstanding possessory rights of the owners of the term.

Sir Orlando Bridgman used the device of a term for years followed by an indestructible executory interest when he drafted the trust indenture to dispose of the barony of Grostock. Bridgman undoubtedly used this method to effectuate the Earl of Arundel's wishes with a certain degree of confidence, borne of his experience as a conveyancer and the sturdiness of the precedents that followed Manning's Case. Even Bridgman would have been somewhat surprised, had he lived, at the extent to which a seemingly straightforward trust instrument was expanded into one of the truly important cases of English legal history.

\section{The Duke of Norfolk's Case}

As previously noted, the judges of the king's courts had been fighting against perpetuities long before the first enunciation of a rule of perpetuities in The Duke of Norfolk's Case. The weapon they had at hand to oppose perpetuities in the two centuries prior to The Duke of Norfolk's Case was principally destructibility of fee tails by the common recovery and of contingent remainders by merger and failure to vest. The early seventeenth century had produced decisions that seriously weakened the effectiveness of this

55 See J. GraY, supra note 7 , at $\$ 121.7$.

50 Scattergood v. Edge, 12 Mod. 278, 281, 88 Eng. Rep. 1320, 1322 (1699).

ธ7 Id. 287.

58 For a discussion of Manning's Case, see text accompanying notes $51-52$ supra; J. Grax, supra note 7 , at $\$ 152$. 
weapon, principally through the recognition of indestructible executory interests. Not only were these decisions unpopular with many of the judges, ${ }^{59}$ they caused considerable confusion concerning the state of the law. ${ }^{60}$ By 1681 both conveyancers and judges were unhappy with the law as it then stood, and both groups found in the 1647 trust indentures of the Earl of Arundel a case that seemed certain to resolve the question that divided them: the definition of what constituted a perpetuity.

Briefly the case was this. The Earl of Arundel and Surrey created two trust indentures that were intended to provide for his family and, more particularly, to guard against the consequences of the insanity of his eldest son Thomas. ${ }^{61}$ After reserving life estates to himself for life and then to his widow the Earl gave to named trustees a term of $\mathbf{2 0 0}$ years, which was followed by remainders to his younger children. Under the trust the term, or more practically the income derived from the barony of Grostock, was to go to the Earl's second son, Henry, and his issue during the life of the eldest son, Thomas; but if Thomas should die without leaving issue in the lifetime of Henry and if, further, Henry should become the Earl by inheritance, Henry was to have no further rights to the rents and profits, which were then to go to the third son, Charles. These, in simplest form, were the limitations of the trust: an absolute equitable interest in the term in Henry ${ }^{62}$ followed by what Lord Nottingham called a springing executory interest in Charles, con-

59 Pells v. Brown and Manning's Case were obviously the two most troublesome precedents.

60 In Snow v. Cutler, I Lev. 135, 1 Keb. 752, 83 Eng. Rep. 335 (1664) the judges seem to have been "in great doubt," yet they did agree that an executory devise "may well be allowed to take place within the compass of a life, but not after a dying without issue, for that would make a perpetuity." 1 Lev. at 136, 83 Eng. Rep. at 336 . One of the judges stated that "if an ordinary contingency ... may determine within one life, or such time, it's good." $2 \mathrm{Keb}$. at 300,84 Eng. Rep. at 187. It is not clear from the report whether dying without issue was intended to mean definite failure of issue, which would not have presented a perpetuity problem under the old law, or indefinite failure, which would have presented a perpetuity under the law before The Duke of Norfolk's Case.

61 The contingency of the insane Thomas' having issue, which troubled the Earl of Arundel, posed no problem for his second son: at the death of his father, Henry arranged to have his elder brother locked up in Padua under circumstances where he was certain not to have an heir. Henry did provide one benefit for his unfortunate sibling. He secured a special act of Parliament restoring to the Howards the family title of "Duke of Norfolk" which had been lost a few generations earlier. Thomas thus became a titled prisoner and at his death his brother Henry became Duke of Norfolk. Barry, supra note 1, at 543-45.

62 There could be no fee tail in a term. Although the first limitation to Henry and the male heirs of his body was an attempt to create the equivalent of a fee tail male in personal property, Henry took an absolute interest and Charles a succeeding executory interest. 
ditioned on the happening of two events which would have to occur within Charles' life if he were to take anything. ${ }^{\text {"s }}$

When Henry in due course succeeded to the Earldom and became Duke of Norfolk, he suffered a common recovery in an effort to terminate his brother Charles' interest. Charles then brought a bill in Chancery to demand the benefit of the term, because the specified conditions to his taking had been fulfilled. The Duke resisted the claim on the ground that the gift to Charles was in the nature of a perpetuity and hence void. This was the issue presented to Lord Chancellor Nottingham to decide: was the gift to Charles a perpetuity? If so, Henry could lawfully retain the interest in the barony of Grostock given him by his father's trust, because the gift to Charles was void.

The issue that divided the judges in this case was not whether perpetuities should be allowed, but what perpetuities were, or more exactly, whether this case presented a perpetuity. On one side it could be argued that the contingency upon which the disposition of the property turned was certain to happen within a short period of time, so it was foolish to refer to the gift as a perpetuity. On the other side, it might be argued that the type of interest created should be found destructible; otherwise the all important preference for free alienability would be compromised. This second argument was the traditional approach to perpetuities and convinced the common law judges Lord Nottingham consulted. The first argument, however, convinced the Chancellor, and was the one that has become the basis for the modern Rule Against Perpetuities. The argument between the two perceptions of what constituted a perpetuity runs through the entire case.

Charles' claim was a sympathetic one, particularly in light of the obvious intent of his father, but the opinion of most of the lower court judges who first heard the case was that Charles' interest was void. In December of 1677 Serjeants Pemberton ${ }^{64}$ and Maynard ${ }^{65}$ gave opinions in favor of Henry. Maynard, unlike Pember-

63 There were successive contingent remainders to other younger brothers, which need not concern us here, and were in any event held invalid by both Lord Nottingham and the common law judges. See Barry, supra note 1, at 546-47.

64 Pemberton was later to advise Nottingham when the case reached Chancery. See text accompanying notes 70-73 infra.

65 Maynard's career is an interesting one. He was in his seventies at the time he heard the case and had been an active supporter of Cromwell during the Civil War. His political sympathies left him in minor posts during the Restoration period, but he lived to see his "good old cause" triumphant again when James II was ousted in the Glorious Revolution of 1688. Maynard served William and Mary as Chancellor until his death at eighty-eight. See J. CAMPBELL, V Lrves of the Chancerlors of Engrand 1-35 (1857). 
ton, was unsure, but ultimately held that Henry's resort to the common recovery was dispositive: "By the Recovery suffered by $H$. $H$. all the Intails [to Charles and his younger brothers] are barred, and consequently the waiting of the Term upon the inheritance destroyed." ${ }^{68}$ This view was later supported by Sir William Jones, who recognized the previous victories of the conveyancers but rejected them: "[T] $]$ he Judges say, as I have often heard them say in other Cases (That if Matthew Manning's Case was now to be adjudged, it would not be so adjudged.)" ${ }^{67}$ The early judges were not unanimous however. Sir William Ellis, an aging Cromwellian, took the conveyancers' side and stood by Pells $v$. Brown. He was impressed with the general sensibility of the estate plan drawn up by Sir Orlando Bridgman. "The Equity and Justice of this Trust carries much Weight with me." 68

Any effort to link these decisions to the economic or political views of the judges is difficult. All of them were landed gentlemen from prominent families. Pemberton was a Tory with connections to the Court. Ellis, the only judge who supported the tying up of land, was a Whig, and therefore connected to the urban, mercantile interests that, according to the traditional interpretation of the origins of the rule, opposed efforts to keep land out of commerce. Maynard and Jones were likewise Whigs and both voted to void Charles' interest. By the time the case reached Chancery two more votes against Charles had been recorded, this time by prominent, perhaps even extreme, Court Tories. ${ }^{69}$ The issue therefore seems to have been approached less from a political than a legal and practical standpoint.

The case finally came before the Chancellor, the Earl of Nottingham, in 1681. Nottingham was so conscious of the importance of the case that he called upon the three chief judges of the common law courts to advise him. ${ }^{70}$ As noted above, one of these judges, Sir Francis Pemberton of the Court of King's Bench, had first heard the case five years before. Since then he had been promoted to King's Bench, apparently to lead the assault on the Whigs, now in disarray after the collapse of their effort to exclude James, the Duke

$683 \mathrm{Ch}$. Cas. at 3, 22 Eng. Rep. at 932.

67 Id. at 5, 22 Eng. Rep. at 933.

68 Id. at 12, 22 Eng. Rep. at 938.

69 See the opinions of North and Montagu, discussed in text accompanying notes $77-84$ infra.

70 The importance of the case cannot be overstated. Nottingham noted that "there are so many Short-hand Writers, that nothing can pass from us here, but it is presently made publick." $3 \mathrm{Ch}$. Cas. at 38, 22 Eng. Rep. at 954. 
of York and heir to the throne, from succession because of his Catholic sympathies. ${ }^{71}$ The King was prepared to strike at his enemies, and Pemberton was considered to be a man "on whom the Court could rely." $72 \mathrm{He}$ was not to last long on the King's Bench, Tory though he was, because he could not match the fury of the King. Pemberton was removed in late 1683, apparently for want of zeal in moving against the Whig Lord Russell. ${ }^{73}$ The other two judges of the common law courts were not as familiar with the case as Pemberton was. Sir William Montagu, Lord Chief Baron of the Exchequer, had a career similar to Pemberton's. ${ }^{74}$ Originally thought to be a reliable supporter of the Crown, he was unwilling to follow it in the mid 1680 's as its positions became increasingly extreme. Montagu was removed from the bench in 1686, for failure to back unreservedly the dispensation power the King sought to strengthen the dissenters and Catholics. Sir Francis North, Chief Judge of Common Pleas, was the most extreme of all three of these judges, and by 1681 he was the Crown's favored judge, more trusted than the Chancellor himself. ${ }^{75}$

The fact that the three common law judges in The Duke of Norfolk's Case opposed Nottingham's decision and that before Lord Nottingham was finally affirmed by the House of Lords in 1685, he was reversed in 1683, provides convincing evidence of the uncertainty that beclouded the opinions of the judges as to what constituted a perpetuity. The unsettled state of the law prevailing in the decades before 1681, and the misunderstanding and inconsistencies of the judges' thinking, are perhaps best illustrated by the separate opinions of the three common law judges whom Lord Nottingham asked to be associated with him in The Duke of Norfolk's Case. As stated, all three disagreed with Nottingham on

I1 The exclusion crisis resulted in a momentary majority for the Whigs in Parliament and a series of bills seeking to exclude James from the succession. For a description of the crisis, which ended in the collapse of the Whig Party and the prosecution of many of the Whig leaders, see D. OGG, supra note 24, at 559-656.

72 D. OGG, supra note 24 , at 624 .

73 I The Dictronary of National Brography 1023 (2d ed. 1953).

i4 Montagu's grandfather was a Puritan gentleman, who was singled out by Stone as an example of a Puritan landowner exceptionally hostile to the values of the bourgeoisie. L. Stone, supra note 20, at 157 (1965). His father was a strong Royalist who paid for his loyalty with a lonely death in the Tower of London in 1644. Montagu followed his father's lead, although he was too young to participate in the Civil War and was rewarded by being made Lord Chief Baron in 1676.

75 J. Canipbell, IV Lives of the Chancellors of England, 302, 310 (1857). 
various grounds and with varying degrees of competence and understanding. ${ }^{6}$

All three of these reliable Tory judges were unwilling to allow Charles to take under the trust indentures because they were unwilling to abandon ancient ideas about destructibility. Lord North said very little, and seems to have understood even less. ${ }^{77}$ Both Pemberton and Montagu, however, clearly saw the issue. They were being asked to abandon the principle of destructibility by common recovery, one of the traditional checks on perpetuities, and they were unwilling to do so. Montagu was the most direct: "[I] such Limitations over were permitted, it would create Perpetuities, which the Law doth abhor." 78 Two strong precedents, Sanders $v$. Cornish ${ }^{79}$ and Child $v$. Baylie, ${ }^{80}$ had rejected limitations turning on a "meer contingency." 81 Moreover, according to Montagu, the precedents pointing the other way were simply wrong. Montagu argued that Pells v. Brown had been controverted by Jay $v$. Jay ${ }^{82}$ where, he said, the judge did "confess Pell and Brown's Case to be adjudged quite contrary to what he argued, yet he tells you, that the Judges did find such Inconveniences arisen upon it . . . ." 83 Accept Pells, argued Montagu, and the ancient legal policy against the tying up of land had to be abandoned:

Admit that Case to be good Law, where will you stop, if you admit the Limitation of a Term after an Estate-tail, where shall it end? For if after one, it may as well be after two; and if after two, then as well after twenty; for it may be said, if he die within twenty Years without Issue, and so if within 100, and there will be no End; and so a Perpetuity will follow. ${ }^{84}$

Pemberton agreed with Montagu, although he would have allowed these particular limitations if created by two separate terms. ${ }^{85}$ He too was conscious of the earlier successes of the conveyancers, and was especially eloquent in his reaction to Manning's Case:

$76 \mathrm{See}$ opinions of Baron Montague, $3 \mathrm{Ch}$. Cas. at 14, 22 Eng. Rep. at 939; Lord Chief Justice North, id. at 20,22 Eng. Rep. at 943; Lord Chief Justice Pemberton, id. at 23, 22 Eng. Rep. at 944; text accompanying notes 77-86 infra. 77 North's opinion may be found at $3 \mathrm{Ch}$. Cas. at 20, 22 Eng. Rep. at 943.

$78 \mathrm{Id}$. at 17, 22 Eng. Rep. at 946.

79 Cro. Car. 230, 79 Eng. Rep. 801 (1631).

8079 Eng. Rep. 393 (1618).

813 Ch. Cas. at 18, 22 Eng. Rep. at 941.

82 Style 258, 274, 82 Eng. Rep. 692, 706 (1651).

$833 \mathrm{Ch}$. Cas, at 19, 22 Eng. Rep. at 942.

84 Id. at 19, 22 Eng. Rep. at 942-43.

$85 \mathrm{Id}$. at 23, 22 Eng. Rep. at 945. 
It was not foreseen nor thought, when that Judgment was given, what would be the Consequence when once there was an Allowance of the Limitation of a Term after the Death of a Person; presently it was discerned, there was the same Reason for after twenty Mens Lives as after one; and so then it was held and agreed, that so long as the Limitation exceeded not Lives in Being at the Creation of the Estate, it should extend so for. . . . and now if this be admitted, no Man can foresee what an ill Effect such an ill Allowance might have there, might such Limitations come in as would incumber Estates and mightily entangle Lands. ${ }^{86}$

If there is a central theme, however, to the three judges' dissents it seems to stem from the case of Child v. Baylie, decided in 1618. The case is important because of its similarity to the interests created by the 1647 trust indenture of the Duke of Norfolk. In Child v. Baylie, a term of years was bequeathed to one $X$, but if $X$ died without issue living at his death, then the term was to go to $Y$. Referring to the ghost of perpetuities, the Court of King's Bench decided that $Y$ 's interest was void, despite the fact that $Y$ 's interest would necessarily take effect within $X$ 's life. When the case came before the Exchequer Chamber in 1623, the judges held, with one strong dissent, that the gift was no different from the entailing of a term, which was void as a perpetuity. Y's interest again was held void. Only the strong bias against perpetuities or ignorance of the law could have produced this result in the face of counsel's argument that the devise was not a fee tail since the second interest was to take effect upon the death of $X$ with no living issue.

Child $v$. Baylie was the authority, despite many contrary decisions which succeeded it, for judges who wished to hew to the line favoring maximum alienability and hence maximum destructibility. This was the position of the three dissenting judges. The arguments forwarded by Montagu, Pemberton and North were the traditional arguments aimed at the efforts of the conveyancers. They did not prevail because the Chancellor, who had the only vote that counted, found the conveyancers' logic more convincing.

Few better examples, of the late seventeenth century Tory can be found than Heneage Finch, Earl of Nottingham and father of the Rule Against Perpetuities. He came from a family of solid Kent gentry, whose senior branch had bought its way into the 
peerage during the inflation of honours under the early Stuarts. Heneage, a son of the cadet branch of the family, married the daughter of a London merchant, Elizabeth Harvey. During the Restoration he sat in Parliament, first for Canterbury and then for Oxford University. Both seats were reliably Tory and Finch's devotion to Anglicanism won him the title of "outstanding Churchman of the Convention" from Sir Keith Feiling, the Tory Party's historian..$^{8 \pi}$ Finch's political positions were in keeping with his party's reputation. He opposed amnesty for the regicides, opposed the payment to the Puritan poet Milton of some money owed him, and supported the "Five Mile Act", which prohibited any dissenting minister from coming within five miles of a market town. ${ }^{88} \mathrm{He}$ generally supported the Royal Court, but was swept up in the antiCatholic enthusiasm of the Popish Plot. ${ }^{\$ 9}$ In 1680 he sentenced Lord Stafford, the aging uncle of Henry and Charles Howard, to death for his alleged role in the plot. Nottingham's staunch Anglicanism had earlier led him to oppose the King in the crisis year of 1673 , when Charles sought to win religious toleration for those who were not members of the Church of England. ${ }^{30}$ He supported the King during the crisis over the succession of James, the Catholic Duke of York, to the throne, but his true feelings on the issue may have been reflected by his son's activity in support of "Limitations" on the Duke of York, a position that James, at any rate, seems to have regarded as more dangerous than exclusion because it would have meant the virtual abandonment of Catholicism. ${ }^{91}$ In sum, Nottingham's political career reflected classic Tory values, with his first loyalty always to the Church, not the King.

By 1681 the newly made Earl of Nottingham was in failing health, and no longer fully trusted by the Crown, which was demanding more complete obedience from its partisans. Some space has been devoted to discussing Nottingham's political views, and

$87 \mathrm{~K}$. Fencing, supra note 24, at 103.

88 J. Camprbelt, IV Ltves of the Chancellors of Engtand 239-4I (1857).

89 See H. Horwitz, Revolution Porticks: The Career of Daniel Finch, SECOND EARI of NotTINGHAM, 1647-1730, at 12 (1968).

90 Daniel, the Earl's son, clearly opposed toleration. See id. 9. According to Campbell, Nottingham himself once offended Charles II by referring to the "Royal Coup" of 1673 in a speech to the Commons. J. Camprele, IV Lrves of THE CHANCELIORS OF ENGLAND 254 (1857). 1673 was a crucial year in English politics, because Royal initiatives in religion, foreign policy and finance were all opposed by the Tory dominated Parliament. Charles II's initiatives ultimately failed and he was forced to turn to the Earl of Danby, who controlled the House through a reliably Tory policy. See D. Witcomage, Charles II and the Cavarier House of CoMmons 1663-1674, at 166-72 (1966).

$91 \mathrm{H}$. Honwriz, supra note 89, at 23 . 
those of his colleagues, not because they were determinative of the case, but rather to illustrate how far removed they were from the bourgeois or liberal views that were thought to have inspired the Rule Against Perpetuities. If any values were reflected in Nottingham's thinking, they were almost certainly those of the landed gentry party to which he belonged. ${ }^{92}$ Accordingly, his opinions in The Duke of Norfolk's Case reflect a balanced but generally tolerant attitude towards the efforts of conveyancers. Nottingham did refer to certain types of conveyances that he would be unwilling to countenance because they tended in the direction of a perpetuity; ${ }^{93}$ but he saw that the old rule against contingent remainders had been bypassed long since by the conveyancers and approved by the judges prompted, he suggested, by "the Nature of Things, and the Necessity of Commerce." 94 These were the very reasons that might have been offered for allowing the common recovery and holding Charles' interest to have been destroyed. Finch was, however, perhaps more sympathetic with the problems faced by a landowner with an heir who was non compos mentis, than he was with the abstract necessity to keep property alienable. Naturally Nottingham relied heavily on Pells $v$. Brown and he rejected Child v. Baylie as a case "that never had any Resolution like it before nor since." 95 In answer to the fears of the other judges, he refused to tell them where he would draw the line, saying only that a line would be drawn when it was needed: "They will perhaps say, where will you stop, if not at Child and Bayly's Case? Where? why everywhere, where there is not any Inconvenience, any Danger of a Perpetuity." 96

The definitions found in The Duke of Norfolk's Case are instructive, for they reflect the thinking of Pells $v$. Brown and Manning's Case as to what constituted a perpetuity, and why and when it would be countenanced. An interest in a term for years or in a freehold estate was, according to the Chancellor, not a perpetuity if the interest conveyed would not last too long, and the test of "too long" became whatever was inconveniently long. Lord

92 There is one notable exception to Finch's generally Tory views. His vote in favor of Irish agricultural imports disgusted his copartisans and was clearly against the economic interest of the gentry.

$933 \mathrm{Ch}$. Cas. at 28-29, 22 Eng. Rep. at 948.

$94 I d$. at 31,22 Eng. Rep. at 950.

$95 \mathrm{Id}$. at 35, 22 Eng. Rep. at 952.

96 Id. at 36,22 Eng. Rep. at 953 . Not surprisingly, a reading of so direct an opinion has led at least one writer to conclude that "the Duke of Norfolk's Case was not a restraint on executory interests but an extension." Bordwell, Alienability and Perpetuities VI, 25 IOWA L. REv. 707, 722 (1940). 
Nottingham noted with approval the decision in Pells v. Brown, where the fee simple was cut short by an executory interest in the lifetime of a living person: such a "Fee upon a Fee" was clearly permissible.97 Another case cited in Nottingham's opinion was Cotton $v$. Heath, ${ }^{98}$ which involved an 18-year term to $A$ followed by a remainder to $B$ for life, remainder to the first issue of $B$ for life. The Chancellor stated that "this Contingent upon a Contingent was allowed to be good, because it would wear out in a short Time." 99 Wood v. Sanders, ${ }^{100}$ decided in 1669, was also cited with approval by Nottingham because the case involved a contingency that would take effect within two lives in being. Nottingham applauded Wood v. Sanders, which was decided by Sir Orlando Bridgman himself and the Earl referred to Bridgman with "great Reverance and Veneration for his Learning and Integrity." 101

Lord Nottingham evidently wished to permit some tying up of land by the "dead hand" and was willing to concede that the ability to control the future ownership of land for at least one lifetime, and probably two, was something the law should allow. What evolved from his decision, however, was not a rule for perpetuities, but a rule of perpetuities. Admittedly, Charles' interest in the term for years was not destructible, but neither should it be void because Charles' interest would "wear itself out" in a single lifetime. Lord Nottingham's resolution of the perpetuities problem was the kind of decision that would please Tory landowners of the 1680's. These landowners did not want complete destructibility, which could ruin the family estate in a generation. They did want freedom to transfer land, but they also wanted some means of protecting the family from lunatics, wastrels, gamblers, and the like by maintaining some degree of control over the future disposition of the land. Lord Nottingham provided them with a compromise between complete alienability and the power to tie up land for a perpetuity. Nottingham's successors were to give even more power to the dead hand, so that in the end the conveyancers and their clients prevailed. What the Chancellor did was consistent with the thinking behind Manning's Case, which validated certain future interests in terms for years and, more importantly, with the logic of Pells $v$. Brown, which had upheld the indestructibility of executory interests.

$97 \mathrm{Id}$.

981 Roll. Ab. 612, Pollex 26, 86 Eng. Rep. 500 (1638).

99 Id. at 35, 22 Eng. Rep. at 952.

$1001 \mathrm{Ch}$. Cas. 131, 22 Eng. Rep. 728 (1669).

$1013 \mathrm{Ch}$. Cas. at 36, 22 Eng. Rep. at 953. 
Nottingham in effect affirmed Pells $v$. Brown though he did not say so explicitly, and thereby laid to rest the doubts that judges nourished about the case for sixty years. The dissent by Doderidge in Pells had reflected the deep-seated conviction that, unless executory interests continued to be freely destructible, freedom of alienation would be curtailed and mischievous perpetuities would be encouraged. The underlying principle of Doderidge's dissent, as above noted, led many judges to repent of the decision and even to favor its reversal. What Nottingham did in relying on Pells $v$. Brown was to underscore the fact that William Brown Jr.'s indestructible executory interest in that decision would necessarily take effect within the life of a single person, namely his brother Thomas. Nottingham viewed Charles' executory interest in The Duke of Norfolk's Case in a similar light: Charles' interest would take effect, if at all, within Thomas' lifetime and hence there existed no perpetuity.

From the standpoint of the evolution of the Rule Against Perpetuities, the decision in Pells $v$. Brown probably did require the eventual formulation of the rule, as has often been asserted; ${ }^{102}$ but ironically Pells provided Lord Nottingham with a very strong precedent for formulating in its initial form the essence of a rule that depends on a measuring life. The Chancellor's definition of a perpetuity as an interest that might exceed the duration of some measuring life was but a small step from the modern definition of a perpetuity as an interest that will not necessarily take effect within a life or lives in being and twenty-one years. The judges of succeeding decades were to formulate the rule in its modern form, but Lord Nottingham effectively took the first step in holding Charles' interest to be valid. Three respectable Tory judges had found the danger of a perpetuity in The Duke of Norfolk's Case, but the Earl of Nottingham saw it differently. The dead hand of the Earl of Arundel needed more room and, aided by Heneage Finch and Sir Orlando Bridgman, it reached back into the world of the living. A great family had to be protected from the control of a lunatic. "It was Prudence in the Earl to take care." 103

\section{CONGLUSION}

It would be too extravagant to state unequivocally that the Earl of Nottingham's decision in The Duke of Norfolk's Case was influenced in whole, or even in part, by his perception of the 
interests of the landed ruling class to which he belonged. The Earl did speak of inconvenience as a test for perpetuities, and he praised the prudence of Orlando Bridgman, one of the greatest ornaments of his profession. These are sentiments that one might expect from a landed gentleman familiar with the need to protect estates, but they can not be said to prove Nottingham's motive for deciding as he did. More probably the Chancellor saw himself as a rationalizer of the confused law of estates and future interests, producing a result that fulfilled a need of the law rather than the interest of any given class. Moreover, the interests of the law and of the landed class were not entirely clear. The common law judges, North, Pemberton and Montagu, were landed gentry of prominent families, and yet they saw in the Earl of Arundel's trust the spectre of perpetuity that they opposed as inimical to both their class and the law. It is perhaps enough to say to them that time proved Nottingham right. No truly permanent perpetuity haunted the land, and the gentry prospered in the eighteenth century.

If the motivation of the creator of the rule, or that of its opponents, may never be entirely clear, it can at least be suggested that the reasons for the rule are not as simple as has been believed. The test of a "life in being", and later a "life in being and twentyone years," was ultimately a compromise, as any limit on the power of a draftsman must be. Compromises generally emerge when an existing structure yields to a rising force. The existing legal structure of the seventeenth century was not one of unchecked perpetuities, but a rigid, already weakened system in which future interests could be found destructible or void and present owners were often comparatively free to break their parents' wills. The rising force of seventeenth century England was not a new capitalist ethic that demanded an end to perpetuities, but a spirit of tolerance for the needs of an increasingly dominant landed class that desperately needed more room to maneuver in order to secure its own future. The rule meant that what had once been considered a perpetuity was one no longer. In this sense the new rule was a clear victory for the "dead hand", not for free alienability. The rule served the fathers, not the sons and if it did not attempt to make lawful a whole panoply of perpetuities, it did at least allow most that were needed. 